УДК 343.34:502.51

DOI dx.doi.org/10.24866/1813-3274/2020-2/125-140

С. И. Голубев ${ }^{1}$

Казанский (Приволжский) федеральный университет, г. Казань, Россия

E-mail: S.Golubev16@rambler.ru

\title{
ВОДЫ И МОРСКАЯ СРЕДА КАК ПРЕДМЕТЫ ПРЕСТУПЛЕНИЯ: ПРАВОМЕРНОСТЬ РЕШЕНИЯ ЗАКОНОДАТЕЛЯ
}

Аннотаичия. В статье рассмотрены вопросы определения предмета преступлений, предусмотренных статьями 250 и 252 УК РФ, а также обстоятельств мест совершения преступления и, что немаловажно, рассматривается понятие водного объекта. На основе анализа нормативных правовых актов дана характеристика морской среды, рассмотрено понятие исключительной экономической зоны. Теоретические положения подкреплены рассмотренными точками зрения видных учёных в сфере экологии. В ходе исследования сделаны выводы о целесообразности замены термина «морская среда» на термин «водный объект», который, в свою очередь, изменит суть уголовно-правовой нормы, содержащейся в ст. 252 УК РФ.

Ключевые слова: экологическая безопасность, вода, морская среда, предмет преступления, водный объект, экологическое преступление, окружающая среда, водный режим.

\author{
Stanislav I. Golubev ${ }^{2}$ \\ Kazan (Volga) Federal University, Kazan, Russia \\ E-mail: tasikitten1@rambler.ru
}

\section{WATERS AND THE MARINE ENVIRONMENT AS OBJECTS OF CRIME: LEGALITY OF THE DECISION OF THE LEGISLATOR}

Abstract. The article discusses the questions of determination of the subject of crimes stipulated by articles 250 and 252 of the criminal code, and the circumstances of the crime scenes and, most importantly, the concept of a water body. Based on the analy-

\footnotetext{
${ }^{1}$ Станислав Игоревич Голубев, кандидат юридических наук, доцент кафедры уголовного права юридического факультета Казанского (Приволжского) федерального университета, Казань, Россия.

Для иитирования: Голубев С. И. Воды и морская среда как предметы преступления: правомерность решения законодателя // Азиатско-Тихоокеанский регион: экономика, политика, право. 2020. № 2. С. 125-140.

${ }^{2}$ Stanislav I. Golubev, Candidate of Law, Associate Professor, Department of Criminal Law, Faculty of Law, Kazan (Volga Region) Federal University, Kazan, Russia.

For citing: Golubev S. I. Waters and the marine environment as objects of crime: legality of the decision of the legislator // PACIFIC RIM: Economics, Politics, Law. 2020. No 1. P. 125-140.
}

(С) Голубев С. И., 2020 
sis of regulatory legal acts, the characteristics of the marine environment are given, and the concept of an exclusive economic zone is considered. The theoretical positions are supported by the points of view of prominent scientists in the field of ecology. The study concludes that it is appropriate to replace the term "marine environment "with the term" water object", which in turn will change the essence of the criminal law norm contained in article 252 of the criminal code of the Russian Federation.

Keywords: environmental safety, water, marine environment, subject of crime, water object, environmental crime, environment, water regime.

В теории уголовного права по вопросу о характеристике предмета преступления, предусмотренного ст. 250 УК РФ, сложились два принципиально разных подхода. Одни авторы, основываясь на буквальном толковании уголовно-правовой нормы, дают химическое определение воды. Так, Н. А. Лопашенко пишет: «Предмет преступления определён в законе; им являются воды, понимаемые как химическое соединение водорода и кислорода, существующее в жидком, твёрдом и газообразном состоянии, и как вся вода, находящаяся в водных объектах» [1, с. 382; 2; 3; 4]. Иной позиции придерживается, например, А. И. Зверева. Она считает, что, хотя в законе и упоминаются воды, на самом деле речь идёт о водных объектах, что и следовало отразить в уголовно-правовой норме [5, с. 102-103; 6; 7; 8; 9]. И. В. Попов подчёркивает, что «по смыслу, заложенному законодателем, ст. 250 УК РФ направлена на охрану водных объектов, а не вод вообще как химического соединения» [10].

Диспозиция анализируемой уголовно-правовой нормы является бланкетной, следовательно, для уяснения смысла уголовно-правового запрета необходимо обратиться как к общему, так и специальному экологическому законодательству. В Федеральном законе от 10 января 2002 г. № 7-Ф3 (в ред. от 27 декабря 2019 г.) «Об охране окружающей среды» [11] понятие рассматриваемого предмета преступления не даётся, а лишь приводятся его виды - поверхностные и подземные воды как компоненты природной среды.

В Водном кодексе РФ (ст. 1) говорится не о воде, а о водном объекте, под которым понимается природный или искусственный водоём, водоток либо иной объект, постоянное или временное сосредоточение вод в котором имеет характерные формы и признаки водного режима. Последнее обстоятельство характеризует изменение во времени уровней, расхода и объёма воды в указанном объекте. Все воды, находящиеся в водных объектах, образуют водные ресурсы, которые используются или могут использоваться. Таким образом, центральным, системообразующим понятием водного законодательства выступает водный объект. О таком его значении, в частности, свидетельствуют принципы водного законода- 
тельства, каждый из которых так или иначе связан не с водой, а с водным объектом. В ст. 3 Водного кодекса РФ указаны, в частности, следующие принципы:

1) значимость водных объектов в качестве основы жизни и деятельности человека. Регулирование водных отношений осуществляется исходя из представления о водном объекте как о важнейшей составной части окружающей среды, среде обитания объектов животного и растительного мира, в том числе водных биологических ресурсов, как о природном ресурсе, используемом человеком для личных и бытовых нужд, осуществления хозяйственной и иной деятельности, и одновременно как об объекте права собственности и иных прав;

2) приоритет охраны водных объектов перед их использованием. Использование водных объектов не должно оказывать негативное воздействие на окружающую среду;

3) сохранение особо охраняемых водных объектов, ограничение или запрет использования которых устанавливается федеральными законами;

4) целевое использование водных объектов. Водные объекты могут использоваться для одной или нескольких целей;

5) приоритет использования водных объектов для целей питьевого и хозяйственно-бытового водоснабжения перед иными целями их использования. Предоставление их в пользование для иных целей допускается только при наличии достаточных водных ресурсов;

6) регулирование водных отношений в границах бассейновых округов (бассейновый подход);

7) регулирование водных отношений в зависимости от особенностей режима водных объектов, их физико-географических, морфометрических и других особенностей;

8) регулирование водных отношений исходя из взаимосвязи водных объектов и гидротехнических сооружений, образующих водохозяйственную систему, и др.

Исходя из этого сторонники признания предметом преступления не воды, а водного объекта делают вывод о рассогласованности уголовного и водного законодательства, отдавая предпочтение последнему.

Справедливости ради надо заметить, что в ст. 223 УК РСФСР 1960 г., предусматривающей ответственность за загрязнение водоёмов и воздуха как преступления против общественной безопасности, общественного порядка и здоровья населения, в качестве рассматриваемого признака назывались реки, озера и другие водоёмы и водные источники.

Оценивая всё это, на первый взгляд действительно можно признать, что предметом преступления, предусмотренного ст. 250 УК РФ, является водный объект. Но дело в том, что в уголовном законе говорится не о воде как таковой (в связи с этим язвительное замечание И. В. Попова, что при таком подходе к определению 
предмета преступления действия виновного можно квалифицировать по ст. 250 УК РФ и при загрязнении воды в плавательном бассейне, когда превышение содержания дезинфицирующих средств нанесло вред здоровью спортсмена [9]), а о поверхностных и подземных водах, источниках питьевого водоснабжения, понятия о которых имеют легальное определение. Поэтому подменять указанный в ст. 250 УК РФ предмет преступления водным объектом нет никаких оснований. Более того, он искажает смысл уголовно-правового запрета.

Так, поверхностные водные объекты состоят из поверхностных вод и покрытых ими земель, естественно они имеют береговые линии (берега) [12]. Исходя из лексического значения, например, слов «берег» и «береговая линия» нетрудно предположить, что они не входят в круг предметов преступления, предусмотренного ст. 250 УК РФ, по определению, но без них, как известно, не может существовать ни один водный объект. Земли, находящиеся под толщей воды, также не могут признаваться предметом указанного преступления.

Исходя из режимных, физико-географических, морфологических и других особенностей выделяются:

а) поверхностные воды - воды, находящиеся на поверхности суши в виде различных водных объектов [13];

б) подземные воды - воды, находящиеся в толще горных пород верхней части земной коры в жидком, твёрдом и газообразном состоянии ${ }^{1}$.

Согласно ст. 5 Водного кодекса РФ к поверхностным водным объектам относятся:

- моря или их отдельные части (проливы, заливы, в том числе бухты, лиманы и др.);

- водотоки (реки, ручьи, каналы);

- водоёмы (озёра, пруды, обводненные карьеры, водохранилища);

- болота;

- природные выходы подземных вод (родники, гейзеры);

- ледники, снежники.

Надо иметь в виду, что внутренние морские воды и мировой океан к предмету рассматриваемого преступления не относятся. Кроме того, как обоснованно полагает Э. Н. Жевлаков, таковым не могут признаваться воды хранилищ, не имеющих экологического значения (отстойники, резервуары, колодцы и т.д.). В случае их загрязнения деяние может признаваться преступлением, посягающим не на экологическую безопасность, а на иные общественные отношения, охраняемые уголовным законом [14, с. 695].

\footnotetext{
${ }^{1}$ В России ведётся государственный водный реестр, представляющий собой систематизированный свод документированных сведений о водных объектах, находящихся в федеральной собственности, собственности субъектов РФ, муниципальных образований, физических и юридических лиц и индивидуальных предпринимателей, об использовании водных объектов в речных бассейнах и бассейновых округах (См.: 38).
} 
К подземным водным объектам Водный кодекс РФ (ст. 5) относит:

бассейны подземных вод - совокупность водоносных горизонтов, расположенных в недрах ${ }^{1}$;

водоносные горизонты - воды, сосредоточенные в трещинах и пустотах горных пород и находящиеся в гидравлической связи. Они классифицируются по трём основаниям: 1) по порядку расположения сверху вниз от земной поверхности; 2) по наличию или отсутствию гидравлической связи с поверхностными водными объектами; 3) по возможности использования в качестве источников централизованного водоснабжения [15].

Понятие источника питьевого водоснабжения сформулировано в ГОСТе 30813-2002 «Вода и водоподготовка. Термины и определения». Под ним понимается водный объект (или его часть), который содержит воду, отвечающую установленным гигиеническим нормативам для источников питьевого водоснабжения, и используется или может быть использован для забора воды в системы питьевого водоснабжения [16, с. 57]. Данное обстоятельство предусмотрено и Водным кодексом РФ. В ст. 43 Кодекса говорится, что для целей питьевого и хозяйственнобытового водоснабжения должны использоваться защищённые от загрязнения и засорения поверхностные и подземные водные объекты, пригодность которых для указанных целей определяется на основании санитарно-эпидемиологических заключений. Это положение корреспондируется с основными принципами водного законодательства, установленного в ст. 3 Водного кодекса РФ. Нормативные правовые установления Кодекса конкретизированы в Правилах охраны поверхностных водных объектов, утверждённых постановлением Правительства РФ от 5 февраля 2016 г. № 79 [17; 18; 19]. Санитарно-эпидемиологические требования к ним закреплены в Федеральном законе от 30 марта 1999 г. № 52-Ф3 (в ред. от 26 июля 2019 г.) «О санитарно-эпидемиологическом благополучии населения» [20].

Порядок использования подземных водных объектов для целей питьевого и хозяйственно-бытового водоснабжения устанавливается законодательством РФ о недрах [21]. Согласно Закону РФ от 21 февраля 1992 г. № 2395-1 (в ред. от 27 декабря 2019 г.) «О недрах» [22] в государственном фонде недр выделены участки, содержащие подземные воды, которые используются для целей питьевого и хозяйственно-бытового назначения [23].

В ст. 252 УК РФ предметом преступления названа морская среда. Её определение в теории уголовного права предопределило дискуссию, в процессе которой сформировались, по нашему мнению, три основных позиции. Первая основана на отнесении морской среды к признакам ряда преступлений. Её, в частности, придерживается Ю. В. Надточий. Она полагает, что на неё посягают преступления,

\footnotetext{
${ }^{1}$ По условиям залегания подземные воды подразделяются на почвенные, грунтовые, межпластовые, артезианские, минеральные.
} 
предусмотренные ст. 252, ч. 1 ст. 253, а также ст. 257, 259, 262 УК РФ [24, с. 51]. Однако нетрудно заметить, что все эти преступления имеют разные предметы, их объединение в одну группу по этому признаку состава преступления является более чем искусственным. Особенно это заметно по включению в неё преступления, предусмотренного ст. 262 УК РФ, предметом которого, как было показано, признаются природные и природно-антропогенные объекты, которые никак не относятся к морской среде.

Кроме того, точка зрения автора внутренне противоречива. С одной стороны, она считает, что все указанные деяния посягают на морскую среду, т.е. последняя в этом случае априори признаётся предметом преступления; с другой стороны - морскую среду называет местом совершения преступления.

Наконец, из числа названных посягательств она выделяет группу преступлений, предметом которых является исключительно морская среда (ст. 252, 253, ч. 2 ст. 256 УК РФ), и группу преступлений, которые направлены в том числе на морскую среду [23]. Наконец, последняя, по мнению Ю. В. Надточий, в преступлении, предусмотренном ст. 252 УК РФ, может выступать его последствием [24, с. 51]. Очевидно, что такая метаморфоза с одним и тем же признаком в одном и том же составе преступления не может быть по определению. Законодательная характеристика преступления также не даёт оснований для такого вывода.

Две другие позиции по поводу сущности предмета преступления расположены на диаметрально противоположных точках одного континуума: одни авторы морскую среду сводят к понятию воды, другие - придают ей собственный смысл, отличный от простого признания её водой.

Н. А. Лопашенко, являясь сторонником первой позиции, морскую среду сводит ко всем видам вод, кроме указанных в ст. 250 УК РФ, признавая в этом случае предметом рассматриваемого преступления «внутренние морские воды РФ, территориальное море РФ, прилежащую зону РФ, исключительную экономическую зону РФ, открытое море, а также континентальный шельф РФ» [1, с. 24] $]^{1}$.

Вначале обратим внимание на очевидный, как нам кажется, момент: необоснованное отнесение к природной среде исключительной экономической зоны РФ и континентального шельфа РФ. Оба эти понятия являются легальными, содержатся в соответствующих федеральных законах. Под исключительной экономической зоной РФ понимается морской район, находящийся за пределами территориального моря РФ и прилегающий к нему, с особым правовым режимом, установленным указанным законом, международными договорами и нормами международного

\footnotetext{
${ }^{1}$ Некоторые авторы, так же характеризуя морскую среду как морские воды, воды внутренних и территориальных морей, прилежащих зон, не относят к ней исключительную экономическую зону РФ и континентальный шельф РФ (см. например: 3, с. 56-57). А. И. Зверева не включает в понятие морской среды континентальный шельф РФ (см.: 5, с. 148).
} 
права (ч. 1 ст. 1 Федерального закона от 17 декабря 1998 г. № 191-Ф3 (в ред. от 27 июня 2018 г.) «Об исключительной экономической зоне Российской Федерации» [26]). Смыслообразующими в этом определении являются два признака: во-первых, морской район, который, во-вторых, имеет особый правовой режим. Последний определён положениями Конвенции ООН по морскому праву 1982 г. Появление исключительной экономической зоны явилось результатом компромисса, достигнутого на Третьей конференции ООН по морскому праву между прибрежными государствами, настаивавшими на расширении границ территориального моря, и государствами, ратовавшими за многостороннюю морскую деятельность. Таким образом, в определении исключительной экономической зоны подчёркивается особый характер правомочий прибрежного государства на ряд видов деятельности.

Кроме того, надо иметь в виду, что понятие исключительной экономической зоны распространяется и на острова, кроме тех, которые не пригодны для поддержания жизни человека или для осуществления самостоятельной хозяйственной деятельности.

Согласно ст. 1 Федерального закона от 30 ноября 1995 г. № 187-Ф3 (в ред. от 28 ноября 2018 г.) «О континентальном шельфе Российской Федерации» [27] континентальный шельф включает в себя морское дно и недра подводных районов, находящихся за пределами территориального моря Российской Федерации на всём протяжении естественного продолжения её сухопутной территории до внешней границы подводной окраины материка. Таким образом, в этом законе ни вода, ни морская среда даже не упоминаются.

Позиция, согласно которой понятие морской среды отождествляется с открытым морем, внутренними морскими водами и территориальным морем РФ, в уголовно-правовой литературе является достаточно распространённой [2], она отличается лишь нюансами. А. И. Зверева, например, считает, что «...системное толкование норм международного и национального права, в том числе регулирующих права прибрежных государств в отношении различных морских пространств, позволяет трактовать открытое море как часть Мирового океана, находящуюся за пределами национальной юрисдикции государств. Такое понимание, на наш взгляд, не позволяет включать открытое море в понятие морской среды для целей реализации уголовной ответственности за её загрязнение» [5]. В литературе было подмечено, что при такой трактовке морской среды авторы ошибочно отождествляют море в пространственном понимании с морской средой [28, с. 27].

Море признавалось предметом преступления по ст. $223^{1}$ УК РСФСР 1960 г. [29]. Причём в заголовке статьи он так и был указан, а в её тексте уже говорилось о внутренних морских и территориальных водах СССР. В этом случае, разумеется, правомерно было определять рассматриваемый признак преступления как море или соответствующие его виды. Кстати сказать, позиция российского законодателя на тот период времени соответствовала международно-правовым актам в сфере противодействия 
загрязнению морей, в частности Международной конвенции по предотвращению загрязнения моря нефтью (Лондон, 1954), Конвенции по предотвращению загрязнения моря сбросами отходов и других материалов (Лондон, 1972) [см.: 30]. Непосредственно из названия этих конвенций явствует, что предметом охраны выступает море.

Однако надо иметь в виду, что в связи с более глубоким проникновением экологических знаний в право уже в тексте последней из упомянутых конвенций, когда говорится о предмете негативного воздействия отходов и других материалов, указывается морская среда (преамбула, ст. 1 и др.). Поэтому море, по нашему мнению, в этом случае характеризуется как обстоятельство места совершения деяния.

В Конвенции ООН по морскому праву (Монтего-Бей, 1982) уже непосредственно говорится о морской среде и дается понятие её загрязнения, исходя из определения которого можно составить представление и о сущности рассматриваемого предмета преступления. В п. 4 ч. 1 ст. 1 Конвенции сказано: «"Загрязнение морской среды" означает привнесение человеком, прямо или косвенно, веществ или энергии в морскую среду, включая эстуарии, которое приводит или может привести к таким последствиям, как вред живым ресурсам и жизни в море, в том числе для рыболовства и других правомерных видов использования моря, снижение качества используемой морской воды и ухудшение условий отдыха». Кроме того, из приведённого определения безусловно вытекает, что морская среда не отождествляется ни с морем, ни с морскими водами.

Указанная трансформация предмета уголовно-правовой охраны, отказ от использования в международно-правовых актах, посвящённых противодействию загрязнению, от термина «море», замена его термином «морская среда» в литературе связывается с развитием морского права. «...Термин “море”, который первоначально возник в морском праве (вероятно, речь должна идти о его использовании в праве, а не возникновении. - Aвm.), отождествлялся со всеми водами Мирового океана и отражал не естественнонаучное понимание, а характеристики, связанные с особенностями установления территориальных границ и юрисдикции государств в отношении различных морских пространств... Понимание же вод Морского океана как объекта, требующего использования разнообразных мер правовой защиты от всевозможных форм загрязнения, появилось относительно недавно. Именно в связи с процессом экологизации всех сфер жизни, в том числе и права, начавшегося в 70-х гг. прошлого века, в международное морское право был введён термин “морская среда" как особый объект правовой охраны» [28].

Основываясь на таком подходе к определению предмета преступления в ст. 224 Модельного уголовного кодекса для государств - участников Содружества Независимых Государств, он был указан как морская среда, так же было рекомендовано поступить и странам, входящим в СНГ. Эта рекомендация реализована, например, в ст. 330 УК Республики Казахстан. 
Н. С. Куделькин, определяя предмет преступления, предусмотренного ст. 252 УК РФ, наряду с морской средой к нему относит: морские биоресурсы (водные биоресурсы); объекты животного и растительного мира; окружающую среду; зоны отдыха; частную и иную собственность; другие объекты материального мира, которым причиняется вред в результате загрязнения морской среды. При этом автор исходит из того, что «включение дополнительного предмета данного преступления, а именно собственности, обоснованно тем, что ч. 2 ст. 252 УК РФ содержит открытый перечень законных интересов, которым может причиняться существенный вред» [31, с. 14].

Такие трактовка предмета и набор объектов в принципе недопустимы. Во-первых, утверждение Н. С. Куделькина не основано на законе, анализируемая уголовно-правовая норма не даёт оснований для констатации такого перечня предмета преступления. Во-вторых, сама идея о выделении дополнительного предмета преступления является теоретически сомнительной; на наш взгляд, допустим лишь перечень его альтернативно указанных видов. В-третьих, нарушено соотношение упоминаемых объектов; окружающая среда охватывает практически все остальные, в чём нетрудно убедиться, обратившись к её трактовке в Федеральном законе «Об охране окружающей среды». В-четвёртых, ошибочным представляется признание предметом преступления какой-либо формы собственности: а) она в принципе не может признаваться таковым, поскольку в уголовном праве выступает объектом преступления (гл. 21 УК РФ); б) признание собственности признаком экологического преступления искажает его правовую природу, поскольку предметом последнего не может быть товар, имущество, т.е. природные ресурсы, овеществляющие в себе конкретный труд человека. Именно по предмету экологические преступления отличаются от преступлений против собственности.

Сложившаяся в теории уголовного права ситуация по предмету преступления, предусмотренного ст. 252 УК РФ, требует оценки достоинств и недостатков каждого из подходов к его трактовке.

По нашему мнению, при характеристике морской среды представители первой позиции фактически раскрывают лишь первую часть определяемого понятия «морская», оставляя без внимания вторую составляющую наименования предмета преступления - «среда», которое означает вещество, заполняющее пространство [32, с. 86-90]. Если же исходить из лексического значения указанных слов, т.е. произвести буквальное толкование рассматриваемого понятия, то можно прийти к выводу, что морская среда - это не только соответствующие воды, но и все живые ресурсы моря, неразрывно связанные со средой обитания [33].

Согласно толковым словарям слово «среда» имеет несколько значений [34, c. 748-749]. В экологии оно означает комплекс природных тел и явлений, с которыми организм находится в прямых или косвенных взаимоотношениях [35, с. 22], 
т.е. всё то, что окружает живое существо в природе. Принято выделять четыре вида среды: наземно-воздушная, водная, почвенная и внутриорганизменная (когда одни живые организмы выступают средой обитания для других организмов) [36, с. 57]. Они отличаются в том числе совокупностью условий жизни организмов, которые могут быть абиотическими или биотическими. Абиотические охватывают комплекс условий неорганической среды, влияющих на организм: свет, температура, вода, воздух, давление, влажность и т.д.; биотические - совокупность влияний жизнедеятельности одних организмов на другие [37, с. 50].

Морская среда выступает составной частью водной среды, в которой обитают разнообразные виды организмов - как животные, так и растения.

Термин «среда» достаточно часто используется в законодательстве, в первую очередь в нормативных правовых актах в сфере экологии. Базовый Федеральный закон «Об охране окружающей среды» в своем названии также содержит его. Окружающая среда выступает родовым понятием по отношению к природной среде, компонентами которой в том числе являются вода и природный объект. Последний представляет собой естественную экологическую систему - объективно существующую часть природной среды, имеющую просранственно-территориальные границы, в которой живые и неживые её элементы взаимодействуют как единое целое и связаны между собой обменом веществ и энергией. Морская среда как часть водной среды отвечает всем данным характеристикам, следовательно, исходя из экологических требований, наделение данного обстоятельства уголовноправовым статусом предмета преступления является вполне обоснованным.

Ю. А. Случевская [28], А. И. Зверева [5] предлагают изменить формулировку рассматриваемого признака преступления, заменив словосочетание «морская среда» указанием на водный объект, который загрязняется при совершении деяний, указанных в ст. 252 УК РФ. При этом авторы исходят из Модельного водного кодекса для государств - участников Содружества независимых Государств [26] и Водного кодекса РФ. В первом из них загрязнение предполагает воздействие на водный объект в результате сброса или поступления в них иным способом, а также образования вредных веществ, которые ухудшают качество поверхностных и подземных вод, ограничивают их использование либо негативно влияют на состояние дна и берегов водных объектов. Как уже указывалось, в п. 4 ст. 1 Водного кодекса РФ также выделяется водный объект.

Предлагаемая замена термина «морская среда» на термин «водный объект» изменит суть уголовно-правовой нормы, содержащейся в ст. 252 УК РФ, поскольку они не являются тождественными; акцент уголовно-правовой охраны сменится вместо всех живых ресурсов моря, неразрывно связанных со средой обитания, он будет сделан на водном объекте как таковом, вместе с его берегами и подводной частью. 


\section{Список литературы}

1. Лопашенко, Н. А. Экологические преступления: уголовно-правовой анализ / Н. А. Лопашенко. - Москва, 2017. - 526 с.

2. Боковня, А. Ю. Загрязнение окружающей среды в уголовном праве / А. Ю. Боковня. - Москва, 2019. - 199 с.

3. Князев, А. Г. Экологические преступления / А. Г. Князев, Д. Б. Чураков, А. И. Чучаев. - Москва, 2009. - 462 с.

4. Комментарий к Уголовному кодексу Российской Федерации (научнопрактический) / под ред. А. И. Чучаева. - Москва : Проспект, 2019. - 1536 с.

5. Зверева, А. И. Экологические преступления, посягающие на безопасность водных объектов: характеристика и разграничение со смежными деликтами / А. И. Зверева. - Москва, 2019. - 200 с.

6. Ачмиз, 3. М. О направлениях оптимизации законодательного описания составов преступлений, сопряженных с загрязнением водных объектов // Российский следователь. - 2014. - № 19. - С. 25-27.

7. Случевская, Ю. А. Объект и предмет преступлений, связанных с загрязнением водных объектов // Уголовное право. - 2015. - № 2. - С. 63-67.

8. Случевская, Ю. А. Гидросфера как объект уголовно-правовой охраны // Экологическое право. - 2015. - № 4. - С. 20-24.

9. Случевская, Ю. А. Конкуренция норм гл. 26 УК РФ, связанных с загрязнением водных объектов // Уголовное право. - 2015. - № 4. - С. 57-62.

10. Попов, И. В. Преступления против природной среды: проблемы теории и практики / И. В. Попов. - Москва : Юрлитинформ, 2012. - 468 с.

11. Об охране окружающей среды : Федеральный закон от 10 января 2002 г. № 7-Ф3 (в ред. от 27 декабря 2019 г.) // Собрание законодательства Российской Федерации. - 2002. - № 2. - Ст. 133 ; 2019. - № 52 (ч. 1). - Ст. 7771.

12. Правила определения местоположения береговой линии (границы водного объекта), случаев и периодичности её определения, утверждённые постановлением Правительства РФ от 29 апреля 2016 г. № 377 (в ред. от 14 декабря 2018 г.) // Собрание законодательства Российской Федерации. - 2016. - № 19. - Ст. 2699 ; 2018. - № 52. - Ст. 8288.

13. ГОСТ 19179-73. Гидрология суши. Термины и определения. - URL: http://docs.cntd.ru/document/gost-19179-73 (дата обращения: 11.03.2020).

14. Уголовный закон в практике районного суда / под ред. А. В. Галаховой. Москва : НОРМА, 2007. - 1023 с.

15. Об утверждении Классификации водоносных горизонтов (первый, второй и иные водоносные горизонты) : приказ Минприроды России от 27 декабря 2016 г. № 679. - URL: http://docs.cntd.ru/document/420389182 (дата обращения: 11.03.2020). 
16. Контроль качества воды : сб. ГОСТов. - Москва : Стандартинформ, 2010. - 944 c.

17. Правила охраны поверхностных водных объектов, утверждённых постановлением Правительства РФ от 5 февраля 2016 г. № 79 // Собрание законодательства Российской Федерации. - 2016. - № 7. - Ст. 989.

18. Долгополов, П. С. Источники питьевого водоснабжения. - URL: http:/www.consultant.ru/cons/cgi/online.cgi?req=doc\&base=CJI\&n=127514\#081572431 429495 (дата обращения: 19.07.2020).

19. Волков, Г. А. Нормативы зон санитарной охраны источников водоснабжения как важнейшее звено эколого-правового механизма // Экологическое право. - 2014. - № 5. - С. 32-38.

20. О санитарно-эпидемиологическом благополучии населения : Федеральный закон от 30 марта 1999 г. № 52-Ф3 (в ред. от 26 июля 2019 г.) // Собрание законодательства Российской Федерации. - 2019. - № 30. - Ст. 4134.

21. Хромов, Е. В. Проблема квалификации незаконного предпринимательства, связанного с незаконной добычей воды // Уголовное право. - 2016. - № 1. C. 74-83.

22. О недрах : Закону РФ от 21 февраля 1992 г. № 2395-1 (в ред. от 27 декабря 2019 г.) // Собрание законодательства Российской Федерации. - 1995. - № 10. Ст. 823 ; 2019. - № 52 (ч. 1). - Ст. 7823.

23. Борисов, А. Н. Комментарий к Закону Российской Федерации от 21 февраля 1992 г. № 2395-1 «О недрах» (постатейный) / А. Н. Борисов, Н. Н. Коблова. URL: http://www.consultant.ru/cons/cgi/online.cgi?req $=$ doc\&base $=$ CMB\&n $=17871 \# 095$ 00244693801991 (дата обращения: 18 июля 2020).

24. Надточий, Ю. В. Преступления, посягающие на морскую природную среду / Ю. В. Надточий. - Владивосток : Изд-во Дальневост. ун-та, 2009. - 204 с.

25. Шарапов, Р. Д. Предмет экологического преступления / Р. Д. Шарапов, А. Ф. Шарипкулова, В. Г. Пушкарев. - Тюмень, 2010. - 160 с.

26. Об исключительной экономической зоне Российской Федерации : Федеральный закон от 17 декабря 1998 г. № 191-Ф3 (в ред. от 27 июня 2018 г.) // Собрание законодательства Российской Федерации. - 1998. - № 51. - Ст. 6273 ; 2018. № $27 .-$ Ст. 3944.

27. О континентальном шельфе Российской Федерации : Федеральный закон от 30 ноября 1995 г. № 187-ФЗ (в ред. от 28 ноября 2018 г.) // Собрание законодательства Российской Федерации. - 1995. - № 49. - Ст. 4694; 2018. - № 49 (ч. 1). Ст. 7515.

28. Случевская, Ю. А. Терминологические проблемы уголовного законодательства в сфере защиты водных объектов // Экологическое право. - 2014. - № 3. С. 26-29. 
29. У Уоловный кодекс РСФСР. - Москва : Госюриздат, 1960. - 174 с.

30. Собрание законодательства Российской Федерации. - 1997. - № 9. URL: http://www.szrf.ru/szrf/oglavlenie.phtml?md=1\&nb=100\&year=1997 (дата обращения: 17.07.2020).

31. Куделькин, Н. С. Юридическая ответственность за загрязнение морской среды : автореф. дис. ... канд. юрид. наук / Н. С. Куделькин. - Москва, 2009. - 26 с.

32. Голубев, С. И. Экологические преступления / С. И. Голубев. - Москва, 2017. -344 c.

33. Дубовик, О. Л. Экологические преступления. Комментарий к главе 26 Уголовного кодекса Российской Федерации / О. Л. Дубовик. - Москва : Спарк, 1998. -352 c.

34. Среда // Толковый словарь русского языка / С. И. Ожегов, Н. Ю. Шведова. - Москва, 1995. С. 748-749.

35. Экология / под ред. В. В. Денисова. - Ростов-на-Дону : Феникс, 2013. - 414 с.

36. Ердаков, Л. Н. Экология / Л. Н. Ердаков, О. Н. Чернышова. - Москва : ИНФРА-М, 2013. - 360 с.

37. Калинина, Е. В. Словарь терминов по экологии / Е. В. Калинина, Л. В. Рудакова, Т. В. Воронкова. - Пермь, 2012. - 146 с.

38. Положение о ведении государственного водного реестра : постановление Правительства РФ от 28 апреля 2007 г. № 253 (ред. от 26.10.2019). - URL: http:/Www.consultant.ru/document/cons_doc_LAW_68034/_ (дата обращения: 18.07.2020).

\section{References}

1. Lopashenko N. A. Ekologicheskie prestupleniya: ugolovno-pravovoi analiz [Environmental crimes: criminal-legal analysis]. Moscow, 2017. 526 p.

2. Bokovnya A. Yu. Zagryaznenie okruzhayushchei sredy v ugolovnom prave [Environmental pollution in criminal law]. Moscow, 2019. 199 p.

3. Knyazev A. G., Churakov D. B., Chuchaev A.I. Ekologicheskie prestupleniya [Environmental crimes]. Moscow, 2009. 462 p.

4. Chuchaev A. I., ed. Commentary on the Criminal Code of the Russian Federation (scientific and practical). Moscow: Prospect Publ., 2019. 1536 p. (In Russian).

5. Zvereva A. I. Ekologicheskie prestupleniya, posyagayushchie na bezopasnost' vodnykh ob"ektov: kharakteristika i razgranichenie so smezhnymi deliktami [Environmental crimes encroaching on the safety of water bodies: characteristics and delimitation with related delicts]. Moscow, 2019. 200 p.

6. Achmiz Z. M. O napravleniyakh optimizatsii zakonodatel'nogo opisaniya sostavov prestuplenii, sopryazhennykh s zagryazneniem vodnykh ob"ektov [On the direc- 
tions of optimization of the legislative description of the offenses associated with water pollution]. Rossiiskii sledovatel', 2014, no. 19, pp. 25-27.

7. Sluchevskaya Yu. A. Ob"ekt i predmet prestuplenii, svyazannykh s zagryazneniem vodnykh ob"ektov [Object and subject of crimes related to water pollution]. Ugolovnoe pravo, 2015, no. 2, pp. 63-67.

8. Sluchevskaya Yu. A. Gidrosfera kak ob"ekt ugolovno-pravovoi okhrany [Hydrosphere as an object of criminal law protection]. Ekologicheskoe pravo, 2015, no. 4, pp. $20-24$.

9. Sluchevskaya Yu. A. Konkurentsiya norm gl. 26 UK RF, svyazannykh s zagryazneniem vodnykh ob"ektov [Competition of the norms of Ch. 26 of the Criminal Code of the Russian Federation related to pollution of water bodies]. Ugolovnoe pravo, 2015 , no. 4, pp. 57-62.

10. Popov I. V. Prestupleniya protiv prirodnoi sredy: problemy teorii i praktiki [Crimes against the natural environment: problems of theory and practice]. Moscow: Jurlitinform Publ., 2012. 468 p.

11. On environmental protection: Federal Law of January 10, 2002 No. 7-FZ (as amended on December 27, 2019). Collection of Legislation of the Russian Federation, 2002, no. 2, art. 133; 2019, no. 52 (part 1), art. 7771. (In Russian).

12. Rules for determining the location of the coastline (boundary of a water body), cases and frequency of its determination, approved by the Government of the Russian Federation dated April 29, 2016 No. 377 (as amended on December 14, 2018). Collection of Legislation of the Russian Federation, 2016, no. 19, art. 2699; 2018, no. 52, art. 8288. (In Russian).

13. GOST 19179-73. Land hydrology. Terms and Definitions. Available at: http:/docs.cntd.ru/document/gost-19179-73 (accessed 11 March 2020). (In Russian).

14. Galakhova A. V., ed. Criminal law in the practice of the district court. Moscow: NORMA Publ,, 2007. 1023 p. (In Russian).

15. On the approval of the Classification of aquifers (first, second and other aquifers): Order of the Ministry of Natural Resources of Russia No. 679 dated December 27, 2016. Available at: http://docs.cntd.ru/document/420389182 (accessed 11 March 2020). (In Russian).

16. Water quality control: collection of GOSTs. Moscow: Standartinform Publ., 2010. 944 p. (In Russian).

17. Rules for the protection of surface water bodies approved by the RF Government Decree of February 5, 2016 No. 79. Collection of Legislation of the Russian Federation, 2016, no. 7, art. 989. (In Russian).

18. Dolgopolov P. S. Istochniki pit'evogo vodosnabzheniya [Sources of drinking water supply]. Available at: http:/www.consultant.ru/cons/cgi/online.cgi?req=do c\&base=CJI\&n=127514\#081572431429495 (accessed 19 July 2020). 
19. Volkov G. A. Normativy zon sanitarnoi okhrany istochnikov vodosnabzheniya kak vazhneishee zveno ekologo-pravovogo mekhanizma [Standards for sanitary protection zones of water supply sources as the most important link in the environmental and legal mechanism]. Ekologicheskoe pravo, 2014, no. 5, pp. 32-38.

20. On the sanitary and epidemiological welfare of the population: Federal Law of March 30, 1999 No. 52-FZ (as amended on July 26, 2019). Collection of Legislation of the Russian Federation, 2019, no. 30, art. 4134. (In Russian).

21. Khromov E. V. Problema kvalifikatsii nezakonnogo predprinimatel'stva, svyazannogo s nezakonnoi dobychei vody [The problem of qualification of illegal entrepreneurship associated with illegal water extraction]. Ugolovnoe pravo, 2016, no. 1, pp. 74-83.

22. On subsoil: the Law of the Russian Federation of February 21, 1992 No. 2395 1 (as amended on December 27, 2019). Collection of Legislation of the Russian Federation, 1995, no. 10, art. 823; 2019, no. 52 (part 1), art. 7823. (In Russian).

23. Borisov A. N., Koblova N. N. Kommentarii $k$ Zakonu Rossiiskoi Federatsii ot 21 fevralya 1992 g. № 2395-1 «O nedrakh» (postateinyi) [Commentary on the Law of the Russian Federation dated February 21, 1992, No. 2395-1 «On mineral resources» (itemized)]. Available at: http://www.consultant.ru/cons/cgi/online.cgi?req=doc\&bas $\mathrm{e}=\mathrm{CMB} \& \mathrm{n}=17871 \# 09500244693801991$ (accessed 18 July 2020).

24. Nadtochiy Yu. V. Prestupleniya, posyagayushchie na morskuyu prirodnuyu sredu [Crimes infringing on the marine environment]. Vladivostok: Publ. house of the Far East. Univ., 2009. 204 p.

25. Sharapov R. D., Sharipkulova A. F., Pushkarev V. G. Predmet ekologicheskogo prestupleniya [The subject of environmental crime]. Tyumen, 2010. $160 \mathrm{p}$.

26. On the exclusive economic zone of the Russian Federation: Federal Law of December 17, 1998 No. 191-FZ (as amended on June 27, 2018). Collection of Legislation of the Russian Federation, 1998, no. 51, art. 6273; 2018, no. 27, art. 3944. (In Russian).

27. On the continental shelf of the Russian Federation: Federal Law of November 30, 1995 No. 187-FZ (as amended on November 28, 2018). Collection of Legislation of the Russian Federation, 1995, no. 49, art. 4694; 2018, no. 49 (part 1), art. 7515. (In Russian).

28. Sluchevskaya Yu. A. Terminologicheskie problemy ugolovnogo zakonodatel'stva $\mathrm{v}$ sfere zashchity vodnykh ob"ektov [Terminological problems of criminal legislation in the field of protection of water bodies]. Ekologicheskoe pravo, 2014, no. 3, p. 26-29.

29. The Criminal Code of the RSFSR. Moscow: Gosyurizdat Publ., 1960. 174 p. (In Russian).

30. Collection of Legislation of the Russian Federation, 1997, no. 9. Available at: http:/www.szrf.ru/szrf/oglavlenie.phtml?md=1\&nb=100\&year=1997 (accessed 17 Jule 2020). (In Russian). 
31. Kudelkin N. S Yuridicheskaya otvetstvennost' za zagryaznenie morskoi sredy [Legal responsibility for pollution of the marine environment]. Cand. Dis. (Legal. Sci.). Synopsis. Moscow, 2009. 26 p.

32. Golubev S. I. Ekologicheskie prestupleniya [Environmental crimes]. Moscow, 2017. 344 p.

33. Dubovik O. L. Ekologicheskie prestupleniya. Kommentarii k glave 26 Ugolovnogo kodeksa Rossiiskoi Federatsii [Environmental crimes. Commentary on Chapter 26 of the Criminal Code of the Russian Federation]. Moscow: Spark Publ., 1998. 352 p.

34. Environment. In: Ozhegov S.I., Shvedova N.Yu. Tolkovyi slovar' russkogo yazyka [Explanatory dictionary of the Russian language]. Moscow, 1995, pp. 748-749.

35. Denisov V. V., ed. Ecology. Rostov-on-Don: Phoenix Publ., 2013. 414 p. (In Russian).

36. Erdakov L. N., Chernyshova O.N. Ekologiya [Ecology]. Moscow: INFRA-M Publ., 2013. 360 p.

37. Kalinina E. V., Rudakova L.V., Voronkova T.V. Slovar' terminov po ekologii [Dictionary of terms on ecology]. Perm, 2012. $146 \mathrm{p}$.

38. Regulations on maintaining the state water register: Resolution of the Government of the Russian Federation of April 28, 2007 No. 253 (as amended on October 26, 2019). Available at: http://www.consultant.ru/document/cons_doc_LAW_68034/ (accessed 18 July 2020). (In Russian). 